\title{
X-ray powder diffraction analysis of a new palladium(II) amino acid complex
}

\author{
Pedro P. Corbi ${ }^{\text {a) }}$ and Antonio C. Massabni \\ Departamento de Química Geral e Inorgânica, Instituto de Química-UNESP, Caixa Postal 355, 14801-970, \\ Rua Prof. Francisco Degni, s/n, Araraquara, SP, Brazil \\ Claudio M. Costa-Neto \\ Departamento de Bioquímica e Imunologia, Faculdade de Medicina de Ribeirão Preto-FMRP, Universidade \\ de São Paulo-USP, 14049-900, Avenida Bandeirantes, 3900 Ribeirão Preto, SP, Brazil
}

(Received 6 October 2003; accepted 9 December 2003)

Powder X-ray diffraction data for a new palladium(II) amino acid complex, of composition $\mathrm{PdC}_{12} \mathrm{H}_{20} \mathrm{~N}_{2} \mathrm{O}_{4} \mathrm{~S}_{2}$, are presented in this paper. Orthorhombic cell parameters are: $a=10.740 \AA, b$ $=19.999 \AA$, and $c=5.2470 \AA$. ( $) 2004$ International Centre for Diffraction Data.

[DOI: $10.1154 / 1.1648317$ ]

Key words: powder diffraction, palladium(II), amino acid

\section{INTRODUCTION}

Cisplatin, or cis-diamminedichloroplatinum(II), has been used for treatment of several human cancers, particularly testicular, ovarian, bladder, head and neck cancer (Jin and Ranford, 2000; Sohn et al., 1997). The anticancer properties of cisplatin were first observed by Barnet Rosenberg at the Michigan State University in 1965, but only in 1978 was this compound approved worldwide for treatment of cancer (Lebwohl and Canetta, 1998). However toxic side effects of cisplatin, mainly nephrotoxicity, neurotoxicity (Sohn et al., 1997) and also ototoxicity (Butour et al., 1997) had limited its use and have led to the development of second generation drugs. The interest to develop new complexes with lower side effects but at the same time with high activity against tumors has stimulated the synthesis of many new complexes. So, new complexes of platinum(II) and their palladium(II) analogues have been prepared and studied as anticancer drugs. Recently, some complexes containing Pt(II) and Pd(II) with mixed ligands such as amino acids and 1,10phenanthroline displayed some cytotoxic activities in vitro against Molt-4, a human leukaemia cell line (Jin and Ranford, 2000). By considering such observations, we prepared a new Pd(II) complex containing in its composition a sulfur amino acid, derived from garlic, and tested the activity of this complex against the proliferation of cancer cells. The preliminary results for the activity in vitro of this new $\mathrm{Pd}(\mathrm{II})$ complex, of composition $\mathrm{PdC}_{12} \mathrm{H}_{20} \mathrm{~N}_{2} \mathrm{O}_{4} \mathrm{~S}_{2}$, showed its potent effect over HeLa tumorigenic cells derived from human cancer (Moreira et al., 2003). Tests in vivo with mice and rats are currently in progress. The present work is dedicated to the X-ray characterization of the complex $\mathrm{PdC}_{12} \mathrm{H}_{20} \mathrm{~N}_{2} \mathrm{O}_{4} \mathrm{~S}_{2}$ using the powder diffraction technique.

\section{EXPERIMENTAL}

Powder microcrystalline $\mathrm{PdC}_{12} \mathrm{H}_{20} \mathrm{~N}_{2} \mathrm{O}_{4} \mathrm{~S}_{2}$ was obtained by reaction of $\mathrm{Li}_{2} \mathrm{PdCl}_{4}$ with the salt of the amino acid de-

a) Electronic mail: pedrocorbi@yahoo.com rived from garlic in methanol under stirring for $2 \mathrm{~h}$. The fine yellow powder formed was filtered, washed with methanol, and dried under $\mathrm{P}_{4} \mathrm{O}_{10}$ in a dessicator. Yield of the synthesis was about $70 \%$. After trituration (mortar and pestle grinding), the $\mathrm{Pd}(\mathrm{II})$ complex was analyzed by using elemental analysis, powder X-ray diffractometry, and thermal analysis.

\section{INSTRUMENTAL CONDITIONS}

Elemental analyses for carbon, hydrogen, nitrogen, and sulfur were performed by using a CHNS-O EA1110 Analyzer, CE Instruments; cysteine was used as a reference substance. Thermal analyses were performed on a Thermoanalyzer TGA/DTA simultaneous SDT 2960 TA Instruments in the following conditions: synthetic air, $100 \mathrm{~cm}^{3} / \mathrm{min}$ and heating rate of $10^{\circ} \mathrm{C} / \mathrm{min}$, from 40 to $900{ }^{\circ} \mathrm{C}$. Powder X-ray analysis was performed on a D 5000 Siemens Diffractometer using $\mathrm{Cu} K \alpha_{1}$ radiation $(\lambda=1.5406 \AA)$ with a graphite diffracted beam monochromator. The sample was scanned over the $2 \theta$ range from $4^{\circ}$ to $70^{\circ}$ in $0.05^{\circ}$ step. The counting time was $1.0 \mathrm{~s} / \mathrm{step}$.

\section{RESULTS AND DISCUSSION}

Elemental analysis for $\mathrm{C}, \mathrm{H}, \mathrm{N}$, and $\mathrm{S}$ in the palladium(II) complex are shown in Table I. According to the experimental data, the composition $\mathrm{PdC}_{12} \mathrm{H}_{20} \mathrm{~N}_{2} \mathrm{O}_{4} \mathrm{~S}_{2}$ is proposed.

TABLE I. Elemental analysis for $\mathrm{PdC}_{12} \mathrm{H}_{20} \mathrm{~N}_{2} \mathrm{O}_{4} \mathrm{~S}_{2}$.

\begin{tabular}{ccc}
\hline \hline Elements & Calculated $(\%)$ & Found $(\%)$ \\
\hline $\mathrm{C}$ & 33.8 & 32.8 \\
$\mathrm{H}$ & 4.70 & 4.80 \\
$\mathrm{~N}$ & 6.60 & 6.40 \\
$\mathrm{~S}$ & 15.0 & 14.7 \\
\hline \hline
\end{tabular}




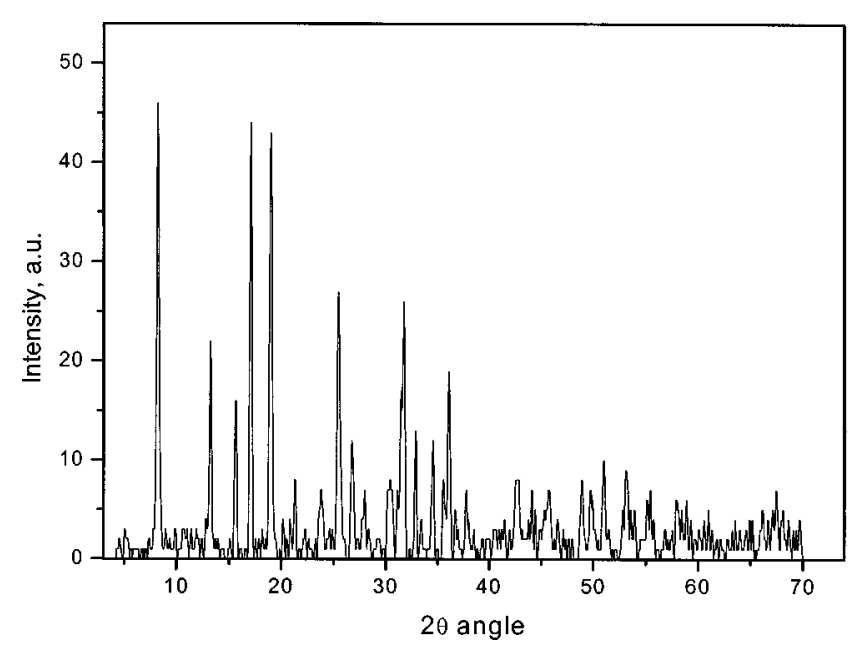

Figure 1. X-ray diffractogram of $\mathrm{PdC}_{12} \mathrm{H}_{20} \mathrm{~N}_{2} \mathrm{O}_{4} \mathrm{~S}_{2}$.

TABLE II. X-ray diffractometry data $\mathrm{PdC}_{12} \mathrm{H}_{20} \mathrm{~N}_{2} \mathrm{O}_{4} \mathrm{~S}_{2}$ (variation $\pm 0.05 \AA$ ).

\begin{tabular}{|c|c|c|c|c|c|}
\hline$I / I_{0}$ & $h$ & $k$ & $l$ & $d_{\text {obs. }}(\AA)$ & $d_{\text {calc. }}(\AA)$ \\
\hline 100 & 1 & 0 & 0 & 10.74 & 10.74 \\
\hline 48 & 0 & 3 & 0 & 6.670 & 6.666 \\
\hline 35 & 1 & 3 & 0 & 5.649 & 5.664 \\
\hline 95 & 2 & 1 & 0 & 5.183 & 5.186 \\
\hline 92 & 0 & 2 & 1 & 4.666 & 4.646 \\
\hline 08 & 1 & 2 & 1 & 4.254 & 4.264 \\
\hline 17 & 0 & 3 & 1 & 4.159 & 4.123 \\
\hline 06 & 0 & 5 & 0 & 3.989 & 4.000 \\
\hline 15 & 1 & 5 & 0 & 3.730 & 3.748 \\
\hline 59 & 2 & 2 & 1 & 3.494 & 3.514 \\
\hline 26 & 0 & 6 & 0 & 3.327 & 3.333 \\
\hline 15 & 1 & 6 & 0 & 3.186 & 3.183 \\
\hline 18 & 3 & 1 & 1 & 2.929 & 2.925 \\
\hline 58 & 0 & 6 & 1 & 2.815 & 2.184 \\
\hline 29 & 1 & 6 & 1 & 2.720 & 2.722 \\
\hline 09 & 3 & 5 & 0 & 2.678 & 2.668 \\
\hline 26 & 4 & 2 & 0 & 2.591 & 2.593 \\
\hline 41 & 4 & 3 & 0 & 2.487 & 2.491 \\
\hline 11 & 1 & 7 & 1 & 2.446 & 2.443 \\
\hline 15 & 1 & 3 & 2 & 2.381 & 2.381 \\
\hline 06 & 1 & 9 & 0 & 2.175 & 2.176 \\
\hline 18 & 3 & 0 & 2 & 2.111 & 2.116 \\
\hline 15 & 4 & 5 & 1 & 2.051 & 2.052 \\
\hline 10 & 2 & 5 & 2 & 2.037 & 2.031 \\
\hline 15 & 5 & 1 & 1 & 1.981 & 1.978 \\
\hline 18 & 4 & 1 & 2 & 1.860 & 1.868 \\
\hline 16 & 4 & 7 & 1 & 1.831 & 1.833 \\
\hline 21 & 6 & 0 & 0 & 1.788 & 1.790 \\
\hline 20 & 0 & 2 & 3 & 1.723 & 1.723 \\
\hline 12 & 4 & 9 & 0 & 1.711 & 1.712 \\
\hline 11 & 1 & 11 & 1 & 1.697 & 1.696 \\
\hline 13 & 2 & 0 & 3 & 1.663 & 1.663 \\
\hline 16 & 5 & 1 & 2 & 1.655 & 1.657 \\
\hline 07 & 2 & 9 & 2 & 1.618 & 1.617 \\
\hline 14 & 0 & 10 & 2 & 1.590 & 1.591 \\
\hline 13 & 3 & 1 & 3 & 1.567 & 1.567 \\
\hline 10 & 7 & 2 & 0 & 1.517 & 1.517 \\
\hline 12 & 7 & 4 & 1 & 1.411 & 1.413 \\
\hline 16 & 5 & 11 & 0 & 1.387 & 1.388 \\
\hline
\end{tabular}

Thermogravimetric analysis has been useful for confirmation of the complex composition as well as for identification of the final residue of the sample after thermal treatment. According to the thermogravimetric data the complex composition was confirmed as being equal to $\mathrm{PdC}_{12} \mathrm{H}_{20} \mathrm{~N}_{2} \mathrm{O}_{4} \mathrm{~S}_{2}$. Ligand oxidation starts at a temperature near $200{ }^{\circ} \mathrm{C}$. Residue composition, after oxidation of the $\mathrm{Pd}(\mathrm{II})$ complex, over $900^{\circ} \mathrm{C}$ was identified by $\mathrm{X}$-ray diffractometry as a mixture of PdO (Powder Diffraction File Database, 1994) and Pd (Powder Diffraction File Database, 1994). Palladium content in the $\mathrm{PdC}_{12} \mathrm{H}_{20} \mathrm{~N}_{2} \mathrm{O}_{4} \mathrm{~S}_{2}$ was quantified by analyzing its thermogravimetric residue at $900{ }^{\circ} \mathrm{C}$ (calculated $24.9 \%$; found $23.7 \%)$.

The powder X-ray diffractogram of $\mathrm{PdC}_{12} \mathrm{H}_{20} \mathrm{~N}_{2} \mathrm{O}_{4} \mathrm{~S}_{2}$ is shown in Figure 1.

Indexing of the experimental $\mathrm{X}$-ray powder diffraction data for $\mathrm{PdC}_{12} \mathrm{H}_{20} \mathrm{~N}_{2} \mathrm{O}_{4} \mathrm{~S}_{2}$ was performed by considering the similarity of the X-ray data collected for this compound in comparison to the orthorhombic form of biotin (Powder Diffraction File Database, 1996). The known data for biotin permitted us to choose the primary cell parameters for $\mathrm{PdC}_{12} \mathrm{H}_{20} \mathrm{~N}_{2} \mathrm{O}_{4} \mathrm{~S}_{2}$ which, after refining, by a least-squares approach, led to the following lattice parameters: $a$ $=10.740 \AA, b=19.999 \AA$, and $c=5.2470 \AA$. The resulting indexation is shown in Table II.

\section{CONCLUSION}

The composition of the new $\mathrm{Pd}(\mathrm{II})$ amino acid complex, of formula $\mathrm{PdC}_{12} \mathrm{H}_{20} \mathrm{~N}_{2} \mathrm{O}_{4} \mathrm{~S}_{2}$, was determined by elemental and thermogravimetric analyses. Thermal decomposition leads to $\mathrm{PdO}$ and $\mathrm{Pd}$ as final products. X-ray diffraction data for $\mathrm{PdC}_{12} \mathrm{H}_{20} \mathrm{~N}_{2} \mathrm{O}_{4} \mathrm{~S}_{2}$ have been successfully indexed on an orthorhombic system with the following cell parameters: $a$ $=10.740 \AA, b=19.999 \AA$, and $c=5.2470 \AA$.

\section{ACKNOWLEDGMENTS}

The authors are grateful to Professor Petr Melnikov (UFMS, Brazil). Financial support: FAPESP and CNPq (Brazilian agencies).

Butour, J. L., Wimmer, S., and Castan, P. (1997). "Palladium(II) compounds with potential antitumor properties and their platinum analogues: A comparative study of the reaction of some orotic acid derivatives with DNA in vitro," Chem. Biol. Interact. 104, 165-178.

Jin, V. X. and Ranford, J. D. (2000). "Complexes of platinum(II) or palladium(II) with 1,10-phenantroline and amino acids," Inorg. Chim. Acta 304, 38-44.

Lebwohl, D. and Canetta, R. (1998). "Clinical development of platinum complexes in cancer therapy: An historical perspective and update," Eur. J. Cancer 34, 1522-1534.

Moreira, A. G., Corbi, P. P., Massabni, A. C., and Costa-Neto, C. M. (2003). "Antiproliferative and cytotoxic effect of a new palladium complex on tumorigenic cells." Book of Abstracts of the XXXII Annual Meeting of the Brazilian Bichemistry and Molecular Biology Society, MG-Brazil, J-31, $125 \mathrm{pp}$.

Powder Diffraction File Database (1996). 30-1556 (JCPDS-ICDD).

Powder Diffraction File Database (1994). 5-0681 (JCPDS-ICDD).

Powder Diffraction File Database (1994). 43-1024 (JCPDS-ICDD).

Sohn, Y. S., Baek, H., Cho, Y. H., Lee, Y., Jung, O., Lee, C. O., and Kim, Y. S. (1997). "Synthesis and antitumor activity of novel polyphosphazene(diamine)platinum(II) conjugates," Int. J. Pharm. 153, 79-91. 